\title{
Insights Learned from Conversion of Web-Based On-Line Courses Back to Traditional Classroom Presentations
}

\author{
Harry C. Petersen, PhD \\ Minnesota State University, Mankato
}

\begin{abstract}
Manufacturing Engineering Technology classes at Minnesota State University in Mankato, Minnesota, including Industrial Safety, and Logistics, had been converted from traditional classroom presentations to web-based on-line classes. We discovered that there were some advantages to on-line courses, such as enhancing presentations, grading homework, and assisting students who missed a class. But, due to time and budget problems and security concerns, these classes were later converted back to classroom presentations again. We found that on-line courses require more time and hardware than traditional classes. There are more costs, some hidden, which also must be considered when developing or converting on-line classes. There are also problems concerning copyright infringement and exam security. This paper provides a case study which discusses reasons for the original conversion, reasons for changing back, and lessons learned concerning presentations, time involved, student progress assessment, scheduling, and results. Information is presented to help departments considering web-based courses with the planning and resource development needs.
\end{abstract}

\section{Advantages of Web Courses - Why Courses were Converted to On Line Delivery}

Two Manufacturing Engineering Technology classes at Minnesota State University in Mankato, Minnesota, Industrial Safety, and Logistics, were converted from traditional classroom presentations to web-based on-line classes. Like many engineering technology departments which are considering development and implementation of new web-based college courses, or converting traditional face-to-face college classes into on-line courses, our primary goal was to reach more students by offering flexibility and reducing travel. There were other advantages we hoped to obtain, as well. ${ }^{1}$

The internet and modern computers and programs offer the opportunity for universities to offer some classes partly or completely over the internet. Mail-order correspondence courses have offered remote learning opportunities for many years, but results and quality of education have been mixed, at best. On the other hand, the internet can provide real-time chat-room discussions, videos, and feedback not possible by mail. Web-based college classes can provide education opportunities to a much wider group of students.

Because our Manufacturing Engineering Technology program includes a two-semester Senior Design Project, some students must travel between the company and the university classes on a regular basis. Some out of town students take the first two years at their local community college, and then complete their four-year Bachelor's of Science degree in Manufacturing 
Engineering Technology here. Web-based courses would allow these students to spend less time away from their homes, saving them money while attracting more students.

We decided to put our senior classes on the web to allow students to take these classes remotely. Because we did not have the faculty or budget to also offer these classes face-to-face, it was initially planned to make all senior classes web-based over a period of years. In 2003, the Minnesota State Colleges and University System (MNSCU) was instituted to assist state campuses in developing on-line curricula and services ${ }^{2}$, and, in 2004, provided grants to the MET program to put classes on-line. ${ }^{1}$ We chose to implement an almost-entirely web-based format, with only one on-campus class meeting per semester to provide lab and presentation time, and one classroom exam. Figure 1 shows the initial plan for course conversion.

Figure 1: 400/500 COURSES CONVERTED FOR 06/07 TO 08/09 ACADEMIC YEAR DELIVERY ${ }^{1}$ :

\begin{tabular}{cccc}
\hline Course Title and Credit & Face-to-Face Component & $\begin{array}{c}\text { First } \\
\text { Online } \\
\text { Ready } \\
\text { Term }\end{array}$ & $\begin{array}{c}\text { Enrolled } \\
\text { Initial } \\
\text { Term }\end{array}$ \\
& &
\end{tabular}

\begin{tabular}{|l|l|c|c|}
\hline $\begin{array}{l}\text { Manufacturing Resource Planning \& } \\
\text { ( } 4 \text { credits) undergraduate }\end{array}$ & Capstone Project Required & $\begin{array}{c}\text { Spring } \\
2006\end{array}$ & 21 \\
\hline $\begin{array}{l}\text { Manufacturing Resource Planning \& } \\
\text { Control } \\
\text { (4 credits) graduate }\end{array}$ & $\begin{array}{l}\text { Capstone and Industry } \\
\text { Applied Project Required }\end{array}$ & $\begin{array}{c}\text { Spring } \\
2006\end{array}$ & 5 \\
\hline $\begin{array}{l}\text { Ergonomics \& Work Measurement } \\
\text { ( } \text { credits) undergraduate }\end{array}$ & Mid term face-to-face Lab & $\begin{array}{c}\text { Spring } \\
2007\end{array}$ & 23 \\
\hline $\begin{array}{l}\text { Project and Value Management } \\
\text { ( } \text { credits) undergraduate }\end{array}$ & Capstone Project Required & $\begin{array}{c}\text { Spring } \\
2006\end{array}$ & 19 \\
\hline $\begin{array}{l}\text { Project and Value Management } \\
\text { (4 credits) graduate }\end{array}$ & Capstone and Industry & Spring \\
\hline $\begin{array}{l}\text { Quality Management Systems } \\
\text { (3 credits) undergraduate }\end{array}$ & Mid term Lab & 3 \\
\hline $\begin{array}{l}\text { Quality Management Systems } \\
\text { (3 credits) graduate }\end{array}$ & $\begin{array}{l}\text { Mid term Lab and Industry } \\
\text { Applied Project }\end{array}$ & Fall 2006 & 23 \\
\hline
\end{tabular}

Industrial Safety (2 credits) and Graduate Industrial Safety were later added to the schedule.

In the process of converting and evaluating these classes, we learned about both the advantages and the costs of our venture. As we proceeded, we found that the opportunities of offering classes on-line came with problems and costs which must be considered. 


\section{Problems and Costs of Web Based Classes- Many are Hidden}

The two most visible costs of offering courses on-line were instructor time and the equipment and programs which on-line courses required.

Additional instructor time required included filming time, studio scheduling and access time, technical training time, editing time, conversion time, time spent editing and verifying web instruction, copyright and license issues, login and downloading student homework, discussions, drop-box access, and preparing many more slides, scanned materials, etc. In some cases this was more than twice the time that would be required for a face-to-face class ${ }^{5}$. Additionally, the Inter Faculty Organization union contract at Minnesota State University does not allow for adequate payment for this extra time, which was often provided by instructors on unpaid weekends.

Another hidden personnel cost was the support staff time required to maintain and correct equipment or program failures and incompatibilities, in addition to the additional instructor time these failures required.

Equipment costs included University studio and audio-visual and editing equipment, servers and storage devices, local computers, computer cameras, green screens, and other materials. Minnesota State University, Mankato, decided to use the D2L on-line delivery system ${ }^{3}$, which is an excellent web-based instructional material delivery system, but must be paid for and maintained.

Other issues, costs, and problems of converting classes to on-line delivery included:

1. Copyrights and intellectual property protection laws, which rises to a new level when putting materials on-line ${ }^{4}$

2. License fees, and the problem of live streaming versus Quick Time downloads

3. Exam and homework integrity, as it is difficult to monitor students,

4. Only one (very intense) day of contact for labs, student presentations, and exams

5. Lack of face-to-face interactive contact with and between students

6. Poor student scheduling of study time meant slipped deadlines and student attempts to do multiple weeks' classes at one time

7. Hardware, equipment, and program compatibility and reliability were continuous problems, especially at start-up

8. Room scheduling was a problem for each single face-to-face meeting, because large blocks of time were required, and the rooms available had already been scheduled for full-semester face-to-face classes.

\section{Assessments, Time, and Budget Motivated Our Return to Traditional Face-to Face Classes}

Each class included a final student assessment survey to monitor class delivery and effectiveness. A majority of students surveyed indicated a slight preference for on-line courses, but many preferred traditional face-to-face classes; and we found that almost all of these students could meet on campus. The type of class affected on-line student learning and preferences. Classes with little or no laboratory content, such as Industrial Safety (MET 424) and Manufacturing 
Resource Planning and Control (MET 407) gave results similar to or slightly better than face-toface classes (See Figure 2):

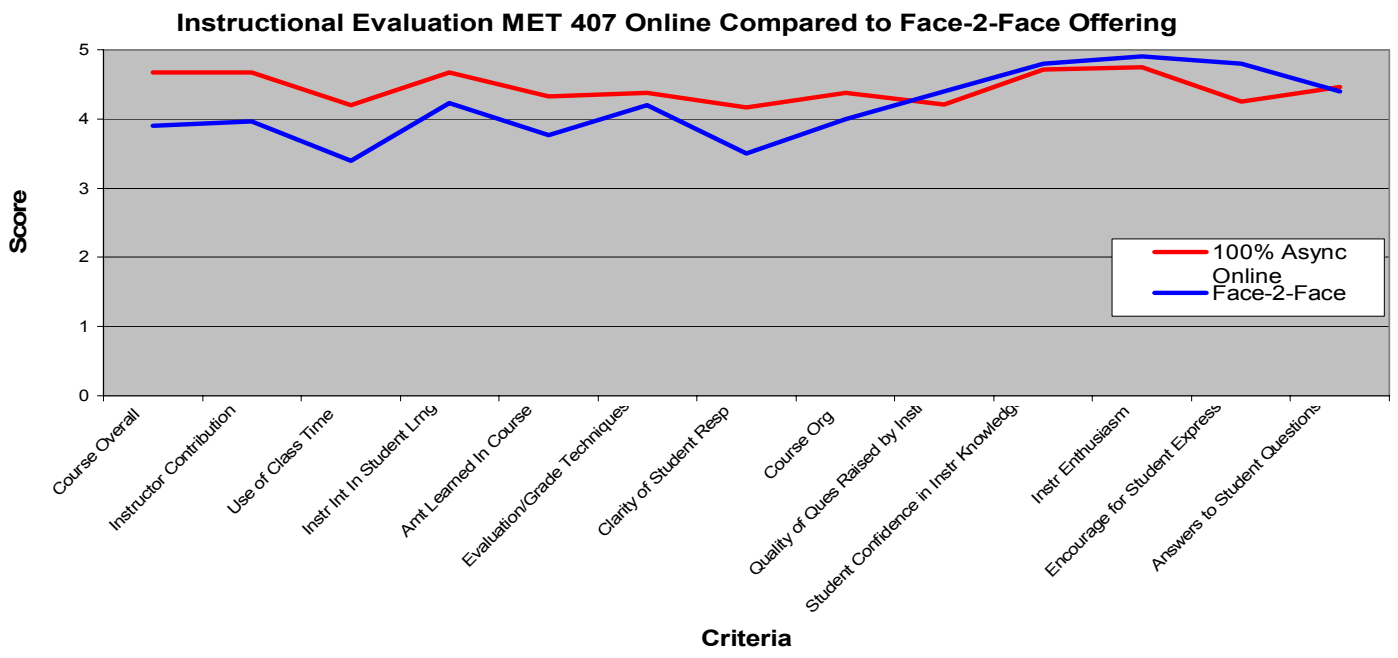

On the other hand, classes with significant laboratory content, such as Ergonomics and Work Measurement (MET 423) did not do so well. Students received much less laboratory experience, depending on the class. Courses like Automation and Robotics (MET 347) were not ever converted to on-line delivery because of the heavy laboratory content.

Grade distributions of on-line classes were similar to the grade distributions on the former faceto-face classes, but a few students did significantly worse on-line than would have been expected, based on past face-to-face performance. Enthusiasm for the material was harder to generate on-line.

We found that there was less opportunity for student-to-student interaction using chat rooms on on-line discussions than occurs in face-to-face classes. Student teams were not really possible except for the single on-campus meeting. Homework, exam, and quiz security was a significant problem, as well.

But some students reported that the on-line classes made learning easier, homework was easier to do because they could review lectures at will, and a number of students reported that the on-line classes made it possible for them to graduate on schedule. Except for team-intensive and labintensive courses, the problems could be mitigated, given enough time and resources, if we had enough time and resources.

However, at this time budgets are tight, and we could not justify added time or dollar costs to continue offering courses on-line. We also found that some on-line college courses were weak 
and of poor quality, which led some universities and employers to question the quality of all web-based courses, including ours. Thus the decision was made to return back to offering traditional face-to-face classes, at the present.

\section{We Converted Back to Face-To-Face Classes, But Retained Many On Line Enhancements}

Although we returned to classroom presentation of courses, in the process we learned that faceto-face traditional courses can benefit from the use of on-line delivery technology. There are some advantages to on-line courses, such as enhancing presentations, grading homework, and assisting students who missed a class, which can be implemented and added to traditional classes with little or no additional time or resource requirements, as long as a good delivery system such as D2L is available. In fact, quizzes administered on-line are much easier to correct, and grades can be posted in a real-time basis using a system such a D2L.

Making Power Point lecture slides which are used in lecture also available to students on-line enables these students to review presentations after class. This also means that they can take fewer notes during lecture, giving them more time to learn and interact. It is quite easy to narrate the Power Point presentations, instead of live filming of lectures, as we found by using narrated Power Points instead of live edited filming when preparing on-line web lectures. In fact, the students preferred narrated Power Point lectures to poorly-filmed lectures with a dim, keystoned, hard to read screen off in the corner. These presentations can be downloaded and reviewed by students multiple times for face-to-face classes, also. This is especially effective when presenting complex calculations.

Handouts can be provided on-line for the students to download, making it unnecessary to duplicate and hand out paper copies during class time. Excel spreadsheets can be used and reviewed by students, and templates provided for complex calculations. Web hyperlinks and videos take students to on-line resources which greatly enhance learning, and take very little preparation time.

By combining the good features of on-line delivery with a single weekly on-campus meeting, the possibility exists to create a new type of hybrid course which combines face-to-face lectures, exams, and labs with on-line delivery of the remainder of the course material. Working students might only need to visit campus once weekly, perhaps on Saturdays.

\section{Conclusions and Recommendations}

There are a number of advantages to on-line courses, such as reaching more students, helping working students, enhancing presentations, grading homework, and assisting students who missed a class.

But on-line courses require more time, programs, and hardware than traditional classes. There are more costs, some hidden, which also must be considered when developing or converting online classes. There are also problems concerning copyright infringement and exam security. 
A more detailed breakdown of the positive and negative aspects of web-based engineering and engineering technology courses can be found in the paper, "Online Engineering Technology Courses - the Good, the Bad, and the Ugly"1. Quality web-based courses require additional commitment of time and resources, but can provide additional benefits to the students. Each course must be carefully evaluated, with as many advantages and disadvantages weighed.

We learned that face-to-face traditional courses can benefit from the use of on-line delivery technology. Putting Power Point lecture slides which were used in lecture on-line also enables students to review presentations and take fewer notes during lecture. Homework and handouts can be provided, and Excel spreadsheets can be used and reviewed by students. Web hyperlinks and videos take students to on-line resources which greatly enhance learning, and take very little preparation time. And the possibility exists to create a new type of hybrid course which combines face-to-face lectures and labs with on-line delivery of the remainder of the course material.

The MET program was successful in putting courses on-line; we just did not have the resources to continue. But the experience gave us the ability to provide an enhanced face-to-face classroom presentation of the courses.

\section{Bibliography}

1. “Online Engineering Technology Courses - the Good, the Bad, and the Ugly", Ms. Ann Goebel, Dr. William Petersen, and Dr. Harry C. Petersen, ASEE International Conference Proceedings, Austin, Texas, June, 2009

2. "Minnesota Online: A System Request to Deliver Programs at a Distance", L. Olson; E-Learning Accreditation Project Director, Office of the Chancellor, Minnesota State Colleges \& Universities, The state university system Office of The Chancellor, October 2003

3. Desire2Learn Inc. 305 King Street West, Suite 200, Kitchener, Ontario, Canada N2G 1B9

4. 2. Circular 21: Reproduction of Copyrighted Works by Educators and Librarians, Library of Congress, United States Copyright Office, Washington DC

5. “Converting Face-to-Face Classes to Web-Based On-Line College Classes" Dr. Harry Petersen and Dr. William Peterson, ASEE International Conference Proceedings, Austin Texas, June 2009. 